\title{
Is Bangladeshi Professionals' Tax-Paying Behavior in Convergence with the Principles of Taxation?
}

\author{
Samia Tarannum Chowdhury ${ }^{1,2}$ \\ ${ }^{1}$ Lecturer, Dept. of Accounting, Faculty of Business and Economics, Monash University, Caulfield East, Victoria \\ 3145, Australia \\ 2 Assistant Professor, Department of Accounting, Faculty of Business Administration, American International \\ University-Bangladesh \\ Correspondence: Samia Tarannum Chowdhury, Department of Accounting, Faculty of Business Administration, \\ American International University-Bangladesh, 83/B, Road No: 04, Kemal Ataturk Avenue, Banani, Dhaka 1211, \\ Bangladesh. E-mail: samia.chowdhury@monash.edu
}

Received: July 21, 2014

doi:10.5430/rwe.v6n3p55
Accepted: August 4, 2014

Online Published: September 18, 2015

URL: http://dx.doi.org/10.5430/rwe.v6n3p55

\begin{abstract}
In an ideal world, it is expected that all people in a civilized society shall pay their fair share of imposed tax. However, reality has a different take on that. People avoid paying the right amount of tax for various reasons. Under such circumstances, it is vital to underpin, if there is a linkage between the taxpaying behavior of people and their professional backgrounds, on the basis of the major taxation principles. This study attempts to identify behavioral pattern of different professional groups in terms of taxation principles, i.e. most commonly known as cannons of equality, cannons of efficiency, cannons of certainty and cannons of convenience. Responses of 18 diverse professional groups have been evaluated and a base line survey, with a structured questionnaire. Over a response gathered from almost 600 participants, using a Likert Scale and open ended questions, the data had been further analyzed using a nonparametric technique. The responses under each of the taxation principles summed up the present divergent tax-paying behavior of the Professional class of Bangladesh. A series of steps that can be taken by the Govt., Private and Multinational Companies and common people in general are suggested to alter and improve the current divergence. If a balanced tax-paying behavior can be achieved, then in future it shall help the Govt. to earn more revenues and reinvest them in the most effective sectors.
\end{abstract}

Keywords: tax principles, taxpaying behavior, convergence, tax, cannons

\section{Introduction}

In an ideal world, it is expected that everyone will pay their respective amount of tax to the government. Taxes collected by a nation, on the other hand, is most likely to be spent on its' aggregated growth, through expenditures in improving its national-defense, communal welfare and wide-ranging administrative activities (Alabede, 2001; Olaofe, 2008, Lymer\& Oats 2008, Martina, Sylvia \&Alfred, 2008), which nowadays in some nations, also includes adaptive measures for anti terrorism courses (Razak and Adafula, 2013). Although, there is this cyclic benefit of tax-payment, people's tax-paying behavior differs from one another. This disparity is evidently expressed, when at the end of each fiscal year, people are busy calculating their taxable income, to figure-out payment of lowest tax possible.

Convergence with tax principles essentially indicates the non-deterrence of taxpaying standards of people. At the same instance, people's perception of being identified and punished for not paying the right amount, or, the amount of tax as a whole, can be termed as tax non-compliance and tax avoidance (Allingham and Sandmo, 1972). Thus, when people follow the general rules of tax payment, it can be termed as convergence with taxation principles. Whereas, the absence of aligning with the above, may be noted as divergence.

In order to have a standard taxation-system for all, Adam Smith, the father of 'modern political economics' had stated four basic principles or canons of taxation, in his book, Wealth of Nations in 1776 (ACCA Policy Paper, 2009). The understanding of a perfect tax principle is incomplete without mentioning Smith's four canons, which are Canon of Equality or Ability, Certainty, Convenience and Efficiency (ACCA Policy Paper, 2009). 
Though there had been many additions and modifications to the principles or cannons of taxation by many economists and policymakers, from time to time, such as Cannon of Productivity, Cannon of Elasticity, Cannon of Simplicity and Cannon of Diversity etc., the earlier mentioned, however, stay to be the most core principles.

There had been enormous amount of studies and research conducted on the basis of taxation worldwide. Nevertheless, not a significant paradigm of research is available on the perspective of taxation adherence of Bangladeshi professionals, on the basis of alignment or misalignment with the principles of taxation. Thus the major aim of this research is to find out, if the professional group of Bangladeshis, are in convergence with the major principles of taxation or not.

The paper has been divided into few segments. For instance, in the following first segment, a portrayal of studies, related to principles of taxation has been stated. It can be noted, that this picturesque representation features both prior and current research findings, perceptions and thoughts of scholars who have studied the subject matter in length and breadth, in various eras of time. Secondly, discussion on research objectives, as well as formation of research hypothesizes have been shaped. Thirdly, a brief narration about the research method that has been used, and respondents' data sampling technique has been discussed. An analysis of the results of the testing is presented in the fourth part of this paper, followed by a discussion in the final part.

\section{Literature Review}

From time to time, much research has been done in terms of tax evasion and tax avoidance of people (Alabede et. al., 2011). Additionally, researchers were intrigued to find out the analogy of taxpaying behavior and taxpaying attitude of people. Tax-paying behavior and attitude towards tax payment of people are also overlapping with the concept of tax avoidance (Feld \& Frey, 2002) and tax non-compliance, as the taxpaying behavior of people are highly correlated with the circumstance and situation that they are in (Morales, 1998, pp 382). Alfonso Morales, in his research (1998, pp 383) also indicated that people greatly practice a tendency, to abide by tax terms, when they deem the tax load or burden, set upon them, as fair and justified. It is also not the first instance that the "fairness" question of tax rate, tax policy has been put on the table. Many researchers have frequently raised their brows to find connectivity amid tax non compliance and tax avoidance with tax-fairness (Hurwich, 2001; Gilligan and Richardson 2005). Earlier studies by the learned society, has always raised a query if the rich are being slashed more (Graetz \& Shapiro, 2005; McGee, 1998a, 1999b, 2004, 2012) and the so called 'not so well-offs' are given unannounced tax cuts (McGee, 1999c).

It can be noted that, the attitude of a tax-payer, shapes his/her tax-paying behavior (BĂRBUȚĂMIŞU, 2011). Various factors participate substantially in determining tax-payers' action of paying tax (Walsh, 2012). Such as tax-payers' monetary condition, risk-taking manner (Alabede, Affrin and Idris, 2011), simplicity of tax-terms, simplicity and burden of tax, may influence a tax-payer's behavior (Chittenden and Foster, 2008). On the contrary, attitude of a taxpayer is shaped by one's culture and individualism (BĂRBUȚĂMIŞU, 2011), one's understanding of the taxation guidelines, both in terms of one's educational capabilities and one's familiarity of the feasible avenues through which tax payment sum can be distorted (Harris, 1989 and Singh, 2003 as cited in Palil and Mustapha, 2011) age (Clotfelter, 1983; Christian \& Gupta, 1992), education, and size of income (Murphy, 2004) as well. Thus it is crucial to recognize whether a person's profession is a noteworthy determinant in one's tax-paying behavior.

The father of Economics, Adam Smith, in his "Wealth of Nations", had particularly gone forward and explained the principles or canons or maxims, as following:

\subsection{Cannon of Equality or Ability}

According to Adam Smith, it refers to "the subjects of every state ought to contribute towards the support of the government, as nearly as possible, in proportion to their respective abilities; that is, in proportion to the revenue which they respectively enjoy under the protection of the state."

In easier words it refers to the fact that all people should be evenly keen to pay their taxes in quantity of their income. This principle also points out that people should pay taxes based on their ability to pay. As a result, people with lower income pay less and people with higher earnings pay more taxes to the government. It also beholds that, the rate or proportion of taxation should increase or decrease, with the increase or decrease of one's income.

\subsection{Cannon of Efficiency or Economy}

Smith explicated "every tax ought to be contrived as both to take out and to keep out of the pockets of the people as little as possible over and above what it brings into the public treasury of the state".

This principle of economy entails that; the expenses of gathering taxes should not be uneven. They are encouraged to be kept at the lowest possible cost-bracket, consistent with administration efficiency. If the state assigns highly 
salaried-staff and absorbs most of the yield, the tax will be considered uneconomical. Tax will also be regarded as uneconomical, if it checks the growth of capital or causes it to immigrate to other countries.

\subsection{Cannon of Certainty}

"The tax which each individual is bound to pay ought to be certain, and not arbitrary. The time of payment, the manner of payment, the quantity to be paid, ought all to be clear and plain to the contributor, and to every other person".

This tax-foundation requires that, there should be an assurance, about the tax-amount, one is supposed to pay in a particular fiscal year. There should also be certainty about when, where and how the tax amount needs to be paid. Consequently, this practice aids in the benefit of both the tax-payer and the state, as both the parties beforehand, how much shall be one's tax expenses and the latter's tax-revenue.

\subsection{Cannon of Convenience}

"Every tax ought to be levied at the time, or in the manner, in which it is most likely to be convenient for the contributor to pay it".

Interestingly, as the original principle of convenience sets forth the comfort of tax-paying time in a taxpayer's life, earlier studies also noted this fact. Lymer and Oats in Chittenden and Foster (2008; pp 43) that tax payment moment, should be set at the most anticipated time, that the payer is supposed to receive one's relevant income and further beholds that, one's payment mode must be as convenient as possible, that is through cheque, cash or online-transfer. Additionally, a study on 'What is "Optimal" Tax System?' by Alm in 1996, there was a preliminary discussion about few basic thoughts, reminiscent of tax efficiency, equity and simplicity that triggered righteous nature of tax-fairness (Alm, 1996, pp 117).

So tax fairness and tax convenience were thought to be a simultaneous discourse to the learneds of the society from an early-on period.

\section{Research Framework}

This study aims to identify if the professional population of Bangladesh have a tax-paying behavior that is in alignment with the principles of taxation. Namely, if the professionals' taxpaying attitude is in convergence with the four principles of taxation, such as cannon or principle of equity, cannon of certainty, cannon of economy and cannon of convenience. Therefore, it can be stated that the specific objective of this study is to identify behavioral pattern of different professional groups in terms of various questions evolving around cannon of equity, cannon of certainty, cannon of economy and cannon of convenience; and recapitulate if the taxpaying manners of Bangladeshi professionals, are convergent or divergent with the principles of taxation.

In order to proceed with the study a series of hypothesis have been constructed. Hypothesizes for the study has been developed considering that, responses against all four behavioral aspects could lead to identify whether tax payers' behavior is influenced by one's profession. As such, the null hypothesizes of this study are:

\section{$\boldsymbol{H}_{1}$ : Bangladeshi peoples' tax-paying behavior is in convergence according to the cannon of equality \\ $\boldsymbol{H}_{2}$ : Bangladeshi peoples' tax-paying behavior is in convergence according to the cannon of economy \\ $\boldsymbol{H}_{3}$ : Bangladeshi peoples' tax-paying behavior is in convergence according to the cannon of certainty \\ $\boldsymbol{H}_{4}$ : Bangladeshi peoples' tax-paying behavior is in convergence according to the cannon of convenience}

\section{Research Methodology}

Samples for the study has been randomly selected from 18 (eighteen) categories of different occupational groups working in Dhaka city (capital of Bangladesh). The occupational list of the sample includes Doctors, Engineers, Government Officers, Businessmen of Small, Medium \& Large Organizations, Bankers, IT Professionals, Accounts Executives, Teachers of Colleges and Universities, CA's and CMA's, Marketing Executives, Human Resource Executives, Lawyers, Retired Officers of Public and Private Sectors and Other Professionals of different occupations not listed above.

For collecting data by a base line survey, a structured questionnaire has been used, where behavioral pattern of the respondents has been measured under principles of taxation. Under this, there are structured questions dependent on the notion of cannon of equity, cannon of certainty, cannon of economy and cannon of convenience. The responses were collected using five-point Likert scale. 
The questionnaire has been sent to 700 individual tax payers. 604 properly filled-up questionnaires were returned back by the respondents. To confirm the quality of the gathered data, a well-trained group of people were engaged in data collection, coding and input stage under the direct supervision of the researcher.

\section{Presentation of Data, Analysis and Findings}

\subsection{Data Presentation}

Nonparametric techniques have been deployed to understand if the there is a strong response to accept or reject the situations under each principle.

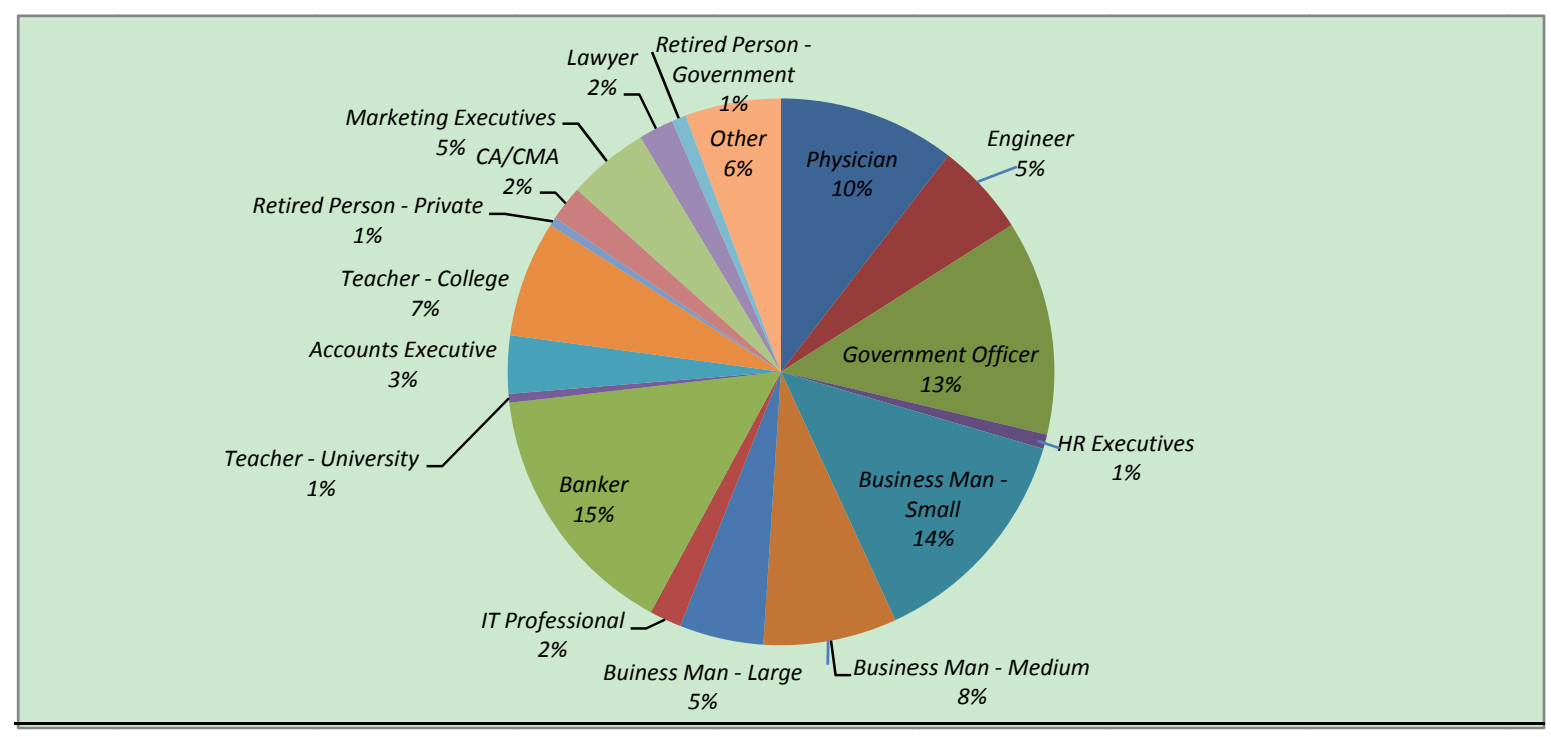

Figure 1. A pie representation of the percentage of professionals in the sample set

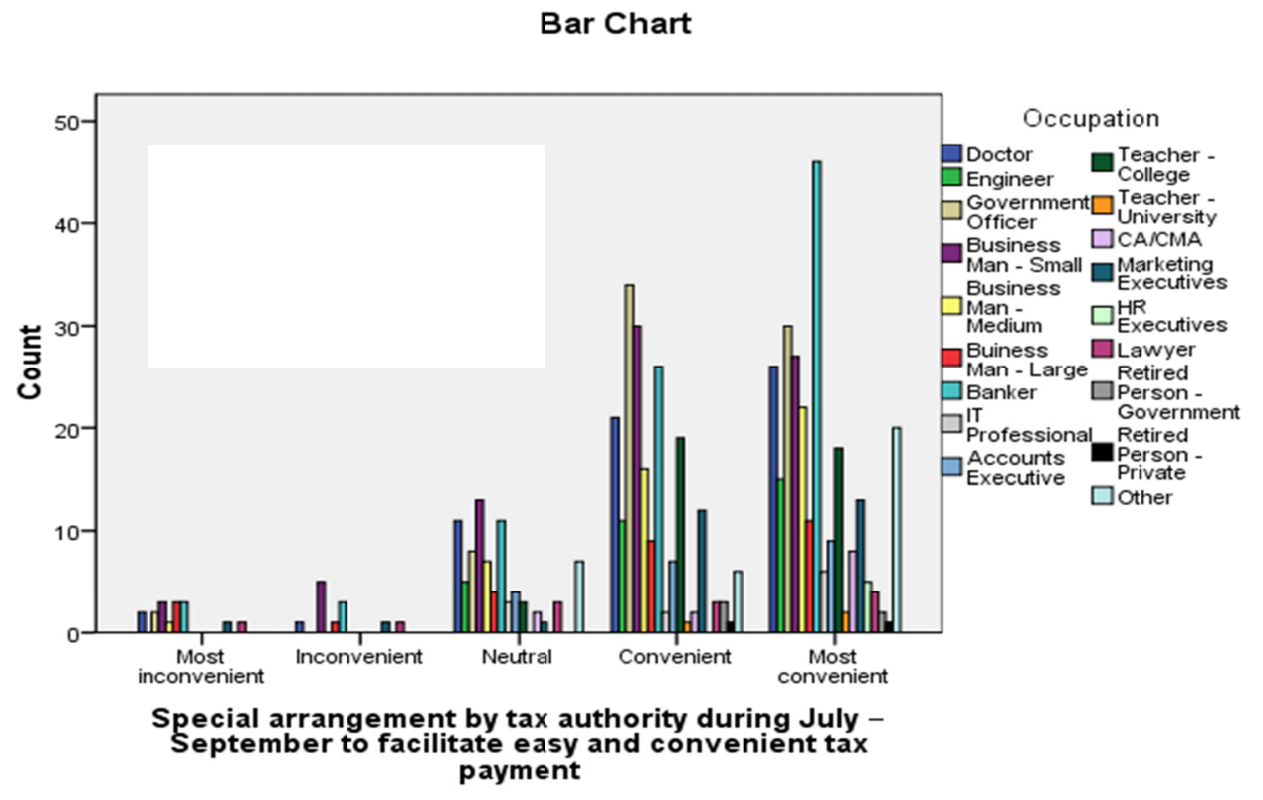

Figure 2. A Bar diagram representation showing responses to a particular survey question 


\subsection{Analysis \& Finding}

\subsubsection{Cannon of Equality}

As understood from the concept, cannon of equality, majorly relates to people's contribution in paying taxes, based on their earning brackets.

The indicators show divergent responses in terms of tax burden not equally justified with respect to others and the charging of same rate of tax is much justifiable than different rates for different income levels. Other than the concept of govt. charging income tax based on their income tax-paying ability of the payers, which is convergent with the cannon of equality. Based on the results of most of the response analysis, it can be recapitulated that the tax-paying behavior of various professionals of Bangladesh are in divergence with the cannon of equality.

\section{$\boldsymbol{H}_{1}$ : Bangladeshi peoples' tax-paying behavior is in convergence according to the cannon of equality \\ $\boldsymbol{H}_{1}$ : Bangladeshi people's tax-paying behavior is not in convergence according to the cannon of equality}

Therefore it can be recapitulated, that professionals prefer on a flat rate of tax to be charged for all. It can be mentioned that, earlier on, a direct comparison of what people pay to and receive in return from the state, also marks the perception of tax levy by the state, as fair or not (Kinsey and Grasmick, 1993). It can be noted here that, cannon of equality is more of a striker on the fairness of the taxation system of any country. In many studies carried in the past, peoples' perception of a fair tax system, has proved to be a critical catalyst with tax convergence in people (Wenzel, 2002, Kinsey and Grasmick, 1993; Kinsey et al., 1991; Mason and Calvin, 1984; Scholz and Lubell, 1998; Thurman et al., 1984; Richardson and Sawyer, 2000). Reasons for Bangladeshi Professionals, preferring a standard rate, rather than different rates for different earners, may be due to the instability in the economic conditions of the state, rate of unemployment, inflation, as well as, people's torment in affording the minimal living standard, in a developing country.

\subsubsection{Cannon of Efficiency or Economy}

The zest of this principle holds that the collection cost of tax should not be more than what it brings inside the govt. treasury collections.

The aspects of govt. charging least amount on people's income as tax and considering payment of income tax as a pressure for people, rather than their willful contribution show divergent responses to the concept of cannon of efficiency or economy. Whereas, tax revenue being sufficient for govt. and thereby govt. needs not to charge more on people exhibit convergence with the principle of efficiency or economy. As a result, it can be summarized that the cannon of efficiency or economy is mostly in divergence with cannon of efficiency or economy.

\section{$\boldsymbol{H}_{2}$ : Bangladeshi peoples' tax-paying behavior is in convergence according to the cannon of economy \\ $\boldsymbol{H}_{2}$ : Bangladeshi peoples' tax-paying behavior is not in convergence according to the cannon of economy}

The efficiency or economic background of a perfect tax-system can be tempered by their tax-paying attitude. This in rotation may be a factor of other social indicators like peoples' social association (Tittle, 1980), their risk taking behavior, or even their nature of occupation like being a job holder or business owner (Torgler \& Schneider, 2006). It was studied by Torgler and Schneider that those, who have their own businesses, are in total discretion of disclosing their taxable income, as a result, it can be harder for job holders to really avoid or manipulate the tax figures, rather the business owners. Interestingly, doctors, lawyers, and accountants - are found to be highly compliant with the tax regulations. Similarly for pensioners and retired individuals, state has a more controlled and translucent payment scheme (Torgler \& Schneider, 2006). Hence, there is only meager scope of divergence from tax-compliance.

\subsubsection{Cannon of Certainty}

Main attention of this principle is on the certainty of the tax amount to be paid, as well as, on the assurance of the place and the procedure of payment.

There is a mixed response in terms of cannon of certainty. There happens to be convergence only in some of the factors under certainty, such as, people knowing their own tax zone, the place where people should pay their taxes, the tax-paying procedure. On the contrary, other response factors like, people knowing how to calculate their taxable income, their knowledge of their applicable tax-paying rate, their knowledge of the time of tax payment, their knowledge about the recent changes in tax laws, their awareness about the consequences of non-payment of income tax, people's familiarity with allowable investment sector to get investment tax benefit and their knowledge of the maximum amount of investment they can show to get investment tax rebate show divergence in alignment with the cannon of certainty. 
As a consequence it can be summed up that majority of the tax-paying indicators are in divergence with the cannon of certainty.
$\boldsymbol{H}_{3}$ : Bangladeshi peoples' tax-paying behavior is in convergence according to the cannon of certainty
$\boldsymbol{H}_{3}$ : Bangladeshi peoples' tax-paying behavior is not in convergence according to the cannon of certainty

\subsubsection{Cannon of Convenience}

It focuses on the convenience of tax-paying time and mode of payment of a tax payer. Taxation convergence through principle of convenience can also be measured by five factors, as identified by Zeithaml and Bitner in 2003 (as cited in Stephenson, 2006). All these factors relate to client's interpretation of satisfactory service while filling tax returns. These factors are: "transitory service intensifier", or tax authority's prompt retort and appropriateness, other apparent service options, taxpayer's self involvement and knowledge about the tax filing process, taxpayer's response to circumstantial incidents, and finally taxpayer's self anticipation of the service available at any particular point in time.

The cannon of convenience shows convergence with people's tax-paying behavior in terms of, people paying tax by themselves and still taking help from others to pay, having a good relationship with the taxation authority and people not having to move from desk-to-desk in order to pay tax. On the other hand, majority of the other features, like people knowing how to pay income tax, the tax-paying procedure being comfortable for themselves, the tax authority officials being cooperative enough, most of the taxation-officials being highly professional, taxation-officials being very efficient demonstrates divergence between the people's tax-paying behavior and the cannon of convenience.

Recapitulation of the cannon of convenience exhibits that most of the factors are divergent to the principle of convenience.

\section{$\boldsymbol{H}_{4}:$ Bangladeshi peoples' tax-paying behavior is in convergence according to the cannon of convenience \\ $\boldsymbol{H}_{4}$ : Bangladeshi peoples' tax-paying behavior is not in convergence according to the cannon of convenience}

Taking the results of all the above hypothesizes, it can be abridged that the tax-paying behavior of the Bangladeshi Professionals are not in convergence with the cannons of taxation. Since all the hypothesis individually is not accepted, on an average, the totality of the hypothesis is thus also not accepted. On an aggregate level, it will not be untrue to hold that the tax-paying behavior of the Professional groups of Bangladesh, are divergent with the principles of a standard taxation system.

\section{Conclusion}

As reiterated, the main rationale of the study was to see if there is a positive alignment and non- deterrence of tax-paying standards among the Bangladeshi professionals from different occupational backgrounds. The major purpose of the research was mainly to encompass the responses around the major principles of taxation, evolving around the cannons of equality, economy or efficiency, certainty and convenience. Through analysis of responses, around many survey-questions of all the cannons or principles of taxation, all have individually unfolded either alignment or misalignment with the tax-paying standards. Summing up of all the responses under each cannon finally aided in drawing a conclusive statement of all the Bangladeshi professionals, about each principles of taxation.

For instance, it had been observed that under the cannon of equality, only tax burden being equally justified with respect to others and the claiming of flat rate of tax is much justifiable than different rates for different income levels have ended with detergency, except that of govt. charging income tax based on their income tax-paying ability of the payers, that gave converging result for testing the hypothesis Thus, summary of the cannon of equality shows, the tax-paying behavior of various professionals of Bangladesh are in divergence with the cannon of equality.

Similarly, under the cannon of economy or efficiency, some of the responses prevailed convergence. They are particularly on the area of tax revenue being enough for govt. and by this means govt. needs not to indict more tax on people. However, issues of govt. charging nominal amount on people's income as tax and allowing for disbursement of income tax as a pressure for people than something they want to do willfully, show divergent responses to the concept of cannon of efficiency or economy. Consequently, it can be stated that the cannon of efficiency or economy is mostly in divergence with cannon of efficiency or economy.

Additionally, convergence under the cannon of certainty happened to be more prominent in the area of people being aware of their own tax zones, tax-paying place and the tax-paying procedure. Conversely, most of the factors under this cannon resulted in divergence to the taxation standards. Namely, they were people's awareness in different areas of certainty. Such as, on the process to calculate their taxable income, their applicable tax-paying rate, time of tax payment, recent changes in tax laws, and their consciousness of the consequences of non-payment of income tax, and 
allowable asset or investment sector to obtain investment tax-benefit and knowing the maximum amount of investment to claim investment tax-rebate, showed divergence with the cannon or principle of certainty. As a summary, there is divergence between people's tax-paying behavior and the cannon of certainty.

The cannon of convenience show convergences between Bangladeshi people's tax-paying behavior and cannon of convenience. Out of which, people paying tax by themselves with the help of others, having a good rapport with the taxation-authority and not having to move from table-to-table to pay tax. However, most of the other indicators akin to people's knowledge about how to pay income tax, procedure of tax-paying being easy for themselves, the taxation-officials being adequately supportive, the taxation-officials being highly skilled, taxation-officials being very proficient, expresses divergence between the people's tax-paying behavior and the cannon of convenience. As a result, the cannon of convenience exhibits to be divergent to the principle of convenience.

In a nutshell, it can be summed up that all the cannons of taxation demonstrate divergence or deterrence of the tax-paying standards among the Bangladeshi professionals.

In order to improve the existing situation there can be informative strategies taken from both Govt. and Private sectors. For instance, media can play an important role in educating people about different issues of cannon of convenience, including the methods to compute their payable tax, their applicable tax-paying rate, time of tax payment, recent changes in tax laws, and their consciousness of the consequences of non-payment of income tax, and allowable investment sector, that can avail investment tax-benefit and informing people about tax-rebate on the highest amount of investment.

The taxation authority can also introduce 'easy-to-use' or 'user-friendly' websites and on-line interactive website that helps people increase their knowledge on the way to pay income tax. The taxation authority can also induce their officials to be cooperative towards the tax-payers, be professional and skilled. The Govt. can introduce local and international training programs and encourage taxation-officials to participate in training programs and conferences both on national and international levels, to tap their skills. Govt. can also reconsider the tax-rate applicable for the earning-class, and modify the tax-rate in order to fine-tune people's complain of the tax burden not being equally justified. A review of the income-bracket and implied tax-rate by the Govt., will also take care of the commons complain for paying income tax as a burden.

Apart from Govt., private companies and Multinational Companies can take-up initiatives to spread the pros and cons of paying the right amount of tax, as part of their Corporate Social Responsibility towards the society, as well. It should be remembered that shaping the society's overall tax-paying behavior can never be led onto the Govt., Private Companies or commons, as their sole responsibility. It is a collective picture and needs to be shaped by the collaborative effort of each and every group of people, inclusive of individualistic and state endeavors.

\section{References}

Abubakari Abdul-Razak, \& Christopher JwayireAdafula. (2013, September). Evaluating taxpayers' attitude and its influence on tax compliance decisions in Tamale, Ghana. Journal of Accounting and Taxation, 5(3), 48-57. http://dx.doi.org/10.5897/JAT2013.0120

Alabede, J. O., Ariffin, Z. Z., \& Idris, M. K. (2011, September). Individual taxpayers' attitude and compliance behaviour in Nigeria: The moderating role of financial condition and risk preference. Journal of Accounting and Taxation, 3(5), 91-104. $\quad$ Retrieved from http://www.academicjournals.org/article/article1379413482_Alabede\%20et\%20al.pdf

Allingham, M. G., \& Sandmo, A. (1972). Income Tax Evasion: A Theoretical Analysis. Journal of Public Economics, 1, 323-38. http://dx.doi.org/10.1016/0047-2727(72)90010-2

Alm, J. (1996, March). What is an Optimal' Tax System?. National Tax Journal, 49(1), 117-133. Retrieved from http://www.ntanet.org/NTJ/49/1/ntj-v49n01p117-33-what-optimal-tax-system.pdf

Bărbuţămişu, N. (2011). A Review of Factors for Tax Compliance, Annals of "Dunarea de Jos". University of Galati Fascicle I. Economics and Applied Informatics, Years XVII - no.1. Retrieved from http://www.ann.ugal.ro/eco/Doc20011_1/Nicoleta_BarbutaMisu.pdf

Chittenden, F., \& Foster, H. (2008). Perspectives on Fair Tax. Discussion Paper, the Association of Chartered Certified Accountants, Manchester Business School, pp.06. Retrieved from https://www.escholar.manchester.ac.uk/api/datastream?publicationPid=uk-ac-man-scw:59414\&datastreamId=F ULL-TEXT.PDF 
Christian, C. W., \& Gupta, S. (1992). New Evidence on Secondary Evasion. The Journal of the American Taxation Association, 72-93.

Clotfelter, C. T. (1983). Tax Evasion and Tax Rates: An Analysis of Individual Returns. Review of Economics and Statistics, 65(3), 363-373. http://dx.doi.org/10.2307/1924181

Feld, L. P., \& Frey, B. S. (2007). Tax compliance as the result of a psychological tax contract: the role of incentives and responsive regulation. Law and Policy, 29, 102-120. http://dx.doi.org/10.1111/j.1467-9930.2007.00248.x

Gilligan, G., \& Richardson, G. (2005). Perceptions of tax fairness and tax compliance in Australia and Hong Kong: A preliaminary study. Journal Financial Crime, 12(4). 331-343. http://dx.doi.org/10.1108/13590790510624783

Graetz, M. J., \& Shapiro, I. (2005). Death by a Thousand Cuts: The Fight over Taxing Inherited Wealth. Princeton \& Oxford: Princeton University Press.

Hurwich, D. (2001, September). Tax Avoidance Discussed. The Chartered Institute of Taxation. Retrieved $5^{\text {th }}$ March 2013, from http://www.tax.org.uk/showarticle.pl?id=491\&n=379

Kinsey, K., \& Grasmick, H. (1993). Did the tax reform act of 1986 improve compliance? Three studies of pre- and post-TRA compliance attitudes'. Law \& Policy, $15, \quad 239-25$. http://dx.doi.org/10.1111/j.1467-9930.1993.tb00111.x

Kinsey, K., Grasmick, H., \& Smith, K. (1991). Framing justice: Taxpayer evaluations of personal tax burdens'. Law and Society Review, 25, 845-73. http://dx.doi.org/10.2307/3053872

Martina, H., Silvia, R., Eric, K., \& Alfred, S. (2008). Procedural Fairness and Tax Compliance. Econ. Analy. Tax Policy, 38(1), 137. http://dx.doi.org/10.1016/S0313-5926(08)50010-5

Mason, R., \& Calvin, L. (1984). Public confidence and admitted tax evasion. National Tax Journal, 37, 489-96.

McGee, R. W. (1999b). An Ethical Look at Paying Your "Fair Share" of Taxes. Journal of Accounting, Ethics \& Public Policy, 2(2), 318-328.

McGee, R. W. (1999c). An Ethical Look at Paying Your "Fair Share" of Taxes. Journal of Accounting, Ethics \& Public Policy, 2(2), 318-328.

McGee, R. W. (2004). The Philosophy of Taxation and Public Finance. Norwell, MA and Dordrecht: Kluwer Academic Publishers. http://dx.doi.org/10.1007/978-1-4419-9140-9

McGee, R. W. (Ed.) (1998a). The Ethics of Tax Evasion. Dumont, NJ: The Dumont Institute for Public Policy Research.

McGee, R. W. (Ed.) (2012). The Ethics of Tax Evasion in Theory and Practice. New York: Springer. http://dx.doi.org/10.1007/978-1-4614-1287-8

Morales, A. (1998, Summer). Income Tax Compliance And Alternative Views Of Ethics And Human Nature. Journal of Accounting, Ethics \& Public Policy, 1(3), 381-399.

Murphy, K. (2004, November). An examination of taxpayers' attitudes towards the Australian tax system: findings from a survey of tax scheme investors. Centre for Tax System Integrity, Working Paper No. 46, Research School of Social Sciences, Canberra: Australian National University.

Palil, M. R., \& Mustapha, A. F. (2011, 21 December). Factors affecting tax compliance behaviour in self-assessment system. African Journal of Business Management, 5(33), 12864-12872.

Richardson, M., \& Sawyer, A. (2001). A Taxonomy of the tax Compliance Literature: Further findings, problems and prospects. Australian Tax Forum, 16, 137-320.

Scholz, J., \& Lubell, M. (1998). Adaptive political attitudes: Duty, trust, and fear as monitors of tax policy. American Journal of Political Science, 42, 903-20. http://dx.doi.org/10.2307/2991734

Singh, V. (2003). Malaysian Tax Administration (6th ed.). Kuala Lumpur: Longman.

Smith, A. The Wealth of Nations, Electronic Vesion. An Electronic Classics Series Publication. Retrieved from http://www2.hn.psu.edu/faculty/jmanis/adam-smith/wealth-nations.pdf

Stephenson, T. (2006). The Gap Between What Taxpayers Want And What Tax Professionals Think They Want: A Re-examination of Client Expectations And Tax Professional Aggressiveness. University of Kentucky Doctoral Dissertations, p.13. 
Thurman, Q., Craig St. J., \& Riggs, L. (1984). Neutralization and Tax Evasion: How effective would a moral appeal be in improving compliance to tax laws? Law and Policy, 6, 309-27. http://dx.doi.org/10.1111/j.1467-9930.1984.tb00329.x

Tittle, C. (1980). Sanctions and Social Deviance: The Question of Deterrence. New York: Praeger.

Torgler, B., \& Schneider, F. (2006). What Shapes Attitudes Toward Paying Taxes? Evidence from Multicultural European Countries. Discussion Paper No. 2117, The Institute for the Study of Labor (IZA) Bonn, pp1-35.

Walsh, K. (2012). Understanding Taxpayer Behaviour-New Opportunities for Tax Administration. Policy Paper, The Economic and Social Review, 43(3), 451-475. Retrieved from http://www.esr.ie/vol43_3/06\%20ESRI\%2043-3\%20Walsh\%20(PP).pdf

Wenzel, M. (2002). The impact of outcome orientation and justice concerns on tax compliance: The role of taxpayers' identity. Journal of Applied Psychology, 87, 629-45. http://dx.doi.org/10.1037/0021-9010.87.4.629 